\title{
Obtaining DNA from Urticaceae: overcoming the challenges associated with chemical compounds and herbarium specimens
}

\begin{abstract}
Obtaining DNA from herbarium collections sometimes becomes of great importance; especially when dealing with rare specimens or when they inhabit areas that are difficult to access, among others. Literature is full with different protocols to extract plant DNA, but not many of them take in to consideration plant material collected for other purposes than DNA extraction. Plant mucilaginous tissues and polyphenols interfere easily with PCR performance. The majority of DNeasy Plant Mini Kit extraction protocols are suitable to extract DNA from fresh material, but not from herbarium material. CTAB-based protocols perform well when extracting fresh or herbarium material, but not when material contains polysaccharides and polyphenols. Urticaceae members produced high amounts of exudate, which interferes with DNA extraction. In this study, we carried out an anatomical analysis for specimens of Urticaceae. We found the presence of polyphenols and polysaccharides. For instance, we proceeded with the development of a suitable protocol to extract DNA from Urticaceae specimens, using both herbarium and field material. The protocol successfully washed off polysaccharide excess and prevented DNA from co-precipitating with polyphenols. Finally, sequenced matK and trnL-F genes from these samples showed to have high-quality chromatograms.
\end{abstract}

Keywords: anatomy, mucilaginous canals, nettle family, polyphenols, polysaccharides
Volume 4 Issue 5 - 2019

\author{
Herber J Sarrazola, Fernado A Alzate \\ Instituto de Biología, Universidad de Antioquia, Colombia \\ Correspondence: Herber J Sarrazola, Instituto de Biología, \\ Universidad de Antioquia, Medellín City, Colombia, Tel \\ 315489|497, \\ Email herber.sarrazola@udea.edu.co,biojassin@gmail.com
}

Received: August 27, 2019 | Published: September 05, 2019

\section{Introduction}

The family Urticaceae Jussieu, known as the nettle family, consists of approximately 54 genera with around 2600 species widely distributed in tropical regions, with few species in temperate zones. Most of its members exhibit high amounts of exudate, cystoliths and calcium carbonate crystals. ${ }^{1-3}$. Economically important genera include many (e.g. Boehmeria Jacq. and Girardinia Gaudich), whose stem fibres are of high quality and therefore used to make cloth, fishing nets, ropes and some industrial materials. Furthermore, some genera, including Elatostema J.R. Forst. \& G. Forst., Pilea Lindl. and Pellionia Gaudich., are dominant and ecologically important elements of the forest floor vegetation in subtropical forests. ${ }^{3-5}$ In the last decade, several papers involving DNA studies on the family have been published. ${ }^{6-16}$ However, DNA extraction and amplification among Urticaceae specimens is problematic.

Many protocols for extracting plant DNA had been reported in literature, but sometimes it is difficult to find a suitable protocol. ${ }^{17,18}$ Some of these protocols are particularly good for extracting DNA from fresh leaves or from tissues preserved using silica gel, while others are specific to target DNA from herbarium material. Extracting DNA from plant material is a significant issue, when tissues are not preserved for DNA extraction; e.g. material which has been dried at high temperatures, treated with ethanol, or in cases where plants contain polysaccharides and polyphenols. ${ }^{19-28}$

Mucilaginous tissues contain proteins associated with polysaccharides, which have been shown to affect the stability of nucleic acids. When these co-precipitate with DNA a compact pellet can be formed, preventing DNA from binding to the polymerase during amplification. ${ }^{29}$ Polyphenols are oxidized at high temperatures, like those used to dry plant material for preservation in herbaria $\left(60^{\circ} \mathrm{C}\right.$ or more), causing these compounds to bind to DNA. This prevents the PCR reaction to take place, as the polymerase cannot target a contaminated DNA molecule. ${ }^{26,30}$

The majority of DNeasy Plant Mini Kit extraction protocols are designed to target fresh material, and are generally suitable for some tissues that contain high levels of polyphenols and mucilaginous compounds like polysaccharides. This can be attributed to the fact that fresh leaves also contain higher amounts of DNA in good conditions, which can allow some DNA molecules to be targeted by the polymerase in spite of the contamination. At the same time, the silica spin columns used in these protocols eliminate many PCR interfering substances. This process does not occur when extracting DNA with other protocols like those based on CTAB (Cetyltrimethylammonium bromide). ${ }^{31}$

A STE-CTAB (Sucrose tris-borate EDTA-CTAB) modified protocol designed by Shepherd et al., ${ }^{32}$ seems to be useful to extract good quality DNA from mucilaginous tissues (as for amplification), as long as the material is fresh (see results for more details on this protocol). The real challenge occurs when trying to extract DNA from plant tissues containing mucilages, polyphenols, and that in addition come from herbarium preserved material. ${ }^{32}$ Drábková et al., ${ }^{22}$ has pointed out that, the drying of plant tissue at high temperatures causes DNA degradation, polysaccharides accumulation and polyphenol oxidation. ${ }^{26-28}$ Another important issue is usually the amount of time that plants have been stored in herbaria, regarding aspects like tissue deterioration and DNA degradation. ${ }^{32}$

Some authors report DNA extraction from plant tissue preserved for up to 200 years, however, it can be easily argued that the older the 
tissue, the more degraded the DNA would be, and less amount of DNA would be obtained. ${ }^{24,27}$ Aspects like fumigation in herbaria to prevent pests, and the method used to preserve specimens can also constitute obstacles to obtain good quality DNA from herbarium material. ${ }^{33}$

Obtaining DNA from herbarium collections can be extremely important, especially when dealing with rare specimens, or when species come from areas of difficult access. For instance, many herbaria refuse destructive sampling of these types of specimens. Using the current protocols, we have faced many difficulties when trying to obtain DNA from herbarium specimens, especially those from the family Urticaceae. Urticaceae has been reported to contain exudates, but it is not clear the type of substances these plants produce (e.g. mucilages or latex). It is also not clear if these substances are present in all Urticaceae. Urticaceae members are also likely to produce polyphenols, since in previous DNA extraction assays we have performed, the ratio A 260/A280 was less than 1.8, indicating proteins and phenols contamination. ${ }^{34}$ Though some authors had successfully extracted chloroplast and nuclear DNA from herbarium Urticaceae specimens, this was done following Doyle and Doyle protocol $^{31}$ with little modifications, with no explanation of what these modifications. ${ }^{3}$ The purpose of this work was to characterise, from an anatomical point of view, the type of factors interfering with DNA extraction and amplification in Urticaceae. At the same time, we evaluated and described a suitable protocol to effectively extract amplifiable DNA from Urticaceae herbarium specimens, containing high amounts of exudate. We developed this protocol combining different techniques adapted from CTAB and DNeasy Plant Mini Kit extraction protocols.

\section{Materials and methods}

\section{Anatomical analysis}

Fresh leaf blades, petioles and young stems from specimens corresponding to Boehmeria aspera Wedd, Boehmeria bullata Kunth, Boehmeria burgeriana, ${ }^{4,5}$ Boehmeria caudata Kunth, Boehmeria celtidifolia Kunth, Boehmeria nivea (L.) Gaudich., Boehmeria pavonii Wedd., Boehmeria ulmifolia Wedd., Pouzolzia occidentalis (Liebm) Wedd., Phenax rugosus (Poir) Wedd and Coussapoa villosa Poepp \& Endl were cut in cross-sections using a microtome, and dyed with safranin-alcian blue. This was done to examine the leaf and stem structures and determine possible sources of DNA extraction interference, such as the presence of mucilaginous cells, laticifers, calcium oxalate and calcium carbonate accumulations. This basic staining technic allows us to observe cell structures in different colours, by polarization of tissues. Structures with high amounts of lignin and secondary cell walls appear stained in read and primary cell walls in blue.

\section{Plant material selection for DNA extraction}

Thirty-six specimens belonging to Urticaceae family were used to extract DNA; twenty-one of them were from herbarium-preserved material and the other fifteen were collected in the field and dried in silica gel. Colombian National Herbarium (COL), Antioquia's University Herbarium (HUA) and National Autonomous University of Mexico Herbarium (MEXU) (Table 1), donated the herbarium material. All vouchers from field specimens were lodged in HUA herbarium (Table 2).
Table I Specimens and vouchers of the plant samples used in this study to extract DNA

\begin{tabular}{|c|c|c|}
\hline Name & Voucher & Source \\
\hline B. aspera & $\begin{array}{l}\text { H.J. Sarrazola } 937 \\
\text { COL } 76768\end{array}$ & $\begin{array}{l}\text { Field } \\
\text { Herbarium }\end{array}$ \\
\hline B. bullata & CHG-46 HUA & Herbarium \\
\hline B. burgeriana & H. J. Sarrazola 952 & Field \\
\hline B. celtidifolia & H. J. Sarrazola 957 & Field \\
\hline B. chiangmaiensis & MEXU 7038I2 & Herbarium \\
\hline B. clidemioides & MEXU5 24004 & Herbarium \\
\hline B. coriacea & $\begin{array}{l}\text { H. J. Sarrazola 83I } \\
\text { H.J. Sarrazola I4I }\end{array}$ & $\begin{array}{l}\text { Herbarium } \\
\text { Field }\end{array}$ \\
\hline B. cylindrica & CUVC 38315 & Herbarium \\
\hline B. densiflora & MEXU 8I6592 & Herbarium \\
\hline B. diffusa & MEXU 652510 & Herbarium \\
\hline B. macrophylla & MEXU 916316 & Herbarium \\
\hline B. nivea & H. J. Sarrazola 960 & Field \\
\hline B. pavonii & H. J. Sarrazola 933 & Field \\
\hline B. pilosiuscula & MEXU 992 & Herbarium \\
\hline B. radiata & MEXU 396688 & Herbarium \\
\hline B. ramiflora & COL 26429 & Herbarium \\
\hline B. tailandica & MEXU 701887 & Herbarium \\
\hline B. tricuspis & MEXU 882232 & Herbarium \\
\hline B. ulmifolia & H. J. Sarrazola 929 & Herbarium \\
\hline B. zollingeriana & MEXU 88035I & Herbarium \\
\hline D. dentata & MEXU 7I I0352 & Herbarium \\
\hline D. orientalis & MEXU I 230084 & Herbarium \\
\hline D. velutina & MEXU 746698 & Herbarium \\
\hline P. formicaria & COL 59382 & Herbarium \\
\hline P. longipes & COL 427I & Herbarium \\
\hline P. occidentalis & $\begin{array}{l}\text { H.J. Sarrazola } 934 \\
\text { COL } 90277\end{array}$ & $\begin{array}{l}\text { Field } \\
\text { Herbarium }\end{array}$ \\
\hline P. parasitica & CUVC 43473 & Herbarium \\
\hline P. poepigiana & MEXU 484I 57 & Herbarium \\
\hline Pouzolzia sp & H. J. Sarrazola 961 & Field \\
\hline Phenax hirtus & COL000I34982 & Herbarium \\
\hline P. mexicanus & CHG-43 HUA & Herbarium \\
\hline P. rugosus & $\begin{array}{l}\text { H.J. Sarrazola } 875 \\
\text { COL } 507710\end{array}$ & $\begin{array}{l}\text { Field } \\
\text { Herbarium }\end{array}$ \\
\hline Phenax sp & H.J. Sarrazola 96I & Field \\
\hline
\end{tabular}


Table 2 Vouchers and GenBank accession codes for specimens sequenced in this study

\begin{tabular}{|c|c|c|c|c|}
\hline Species & Gen & GenBank code & Specimen Voucher & Herbarium \\
\hline \multirow[t]{2}{*}{ Boehmeria_aspera_5 } & matK & MHI5I3I5 & H. J. Sarrazola 937 & HUA \\
\hline & trnL-F & MHI5I324 & & \\
\hline Boehmeria_bullata_30 & matK & MHI5I320 & CHG-46 & HUA \\
\hline \multirow[t]{2}{*}{ Boehmeria_celtidifolia_35 } & matK & MHI5I323 & H.J. Sarrazola 957 & HUA \\
\hline & $\operatorname{trnL-F}$ & MHI5I327 & & \\
\hline \multirow[t]{2}{*}{ Boehmeria_pavonii_22 } & matK & MHI5I3I9 & H.J. Sarrazola 933 & HUA \\
\hline & $\operatorname{trnL-F}$ & MHI5I326 & & \\
\hline \multirow[t]{2}{*}{ Boehmeria_ulmifolia_I3 } & matK & MHI5I3I7 & H. J. Sarrazola 929 & HUA \\
\hline & $\operatorname{trnL}-\mathrm{F}$ & MHI5I325 & & \\
\hline Phenax_hirtus_20 & matK & MHI5I3I8 & COL000I34982 & $\mathrm{COL}$ \\
\hline Phenax_mexicanus_3I & matK & MHI5I32I & $\mathrm{CHG}-43$ & HUA \\
\hline Phenax_sp_33 & matK & MHI5I322 & COL0003II2I3 & $\mathrm{COL}$ \\
\hline Pouzolzia_sp_6 & matK & MHI5I3I6 & H. J. Sarrazola 96I & HUA \\
\hline
\end{tabular}

DNA pre-extraction procedure before extracting DNA, we followed the next steps

$20 \mathrm{mg}$ of every sample (portions of leaves) was weighted, and deposited on a $1.5 \mathrm{ml}$ microcentrifuge tube. We tested the efficiency (time consumed and leaf pulverization) of liquid nitrogen and 1/8 inches carbon steel balls to grind tissues. We used two types of leaves. A type of leaves of thin texture and with tendency to possess trichomes in the form of arachnoid tomentum. A second type of leaves of coarse texture and with a tendency to fracture upon contact with the hand or other object. In the first case, $1.5 \mathrm{ml}$ microcentrifuge tubes were suspended in liquid nitrogen and the samples were mashed using a glass mixer until obtaining a fine powder. In the second one, three balls were added to every tube, which were vortexed at 2500rpm, for at least $5 \mathrm{~min}$ or until observing a fine powder.

\section{DNA extraction}

We tested five protocols for extracting DNA; four from literature, designed to target herbarium and field material and the last one was a selection of some steps among the others to standardize a new one, combining the best qualities among them, to successfully extract DNA from Urticaceae specimens. We used as starting point the January 2011 released version of the standard Dneasy Plant Mini $\mathrm{Kit}{ }^{\circledR}$; which is design to extract DNA from both herbarium and field material (we used this version since the buffers in our lab are based on it, but any version could be suitable for this purpose). We then proceeded with the second protocol a modification of the first; the Dneasy Plant Mini Kit (QIAgen) for Plants with Leaves Containing Sclerenchyma Strands. ${ }^{22}$

Third and fourth protocols were based on CTAB, mainly those modified after Doyle $\mathrm{e}^{31}$ and that have been reported to be useful to extract DNA from herbarium material. We tested the STE/CTAB Method for Microscale DNA Extraction from Polysaccharide-Rich Plants, ${ }^{22}$ and another protocol based on CTAB, published and designed to obtain DNA from both herbarium and field specimens. ${ }^{35}$

Finally, we used a protocol that we standardized by combining elements from the others above mentioned, and we performed some modifications regarding time of centrifugation, amount of added solutions, among others. The step two is a crucial inclusion in this protocol, since not often CTAB-based protocols contain such step (view protocol), but it is necessary in order to remove polysaccharides. The use of $0.1 \%(\mathrm{v} / \mathrm{v}) \beta$-mercaptoethanol in step four is also of great importance as it avoids the co-precipitation of polyphenols with DNA. These days many protocols refuse to use this compound as it is supposed to be a highly contaminant product. However, we standardised the protocol using a low quantity of this compound, only $3.0 \mu \mathrm{L}$ per sample. The step 14 is also a good improvement for a CTAB-based protocol, because it allows us to choose between two different approaches, depending on the quality and quantity of precipitated DNA. If DNA forms a pellet, we can end with steps 15 and 16, washing and cleaning DNA, but if the pellet is not formed (as when using herbarium samples), we proceed with a more complex procedure in step 17. Using mini spin columns (or other type of columns) for filtering is another improvement in a CTAB protocol, as it is something only seen in manufactured ones. In spite that the methods implemented to ovoid DNA to co-precipitate with other compounds, after long hours of precipitation, it can happen. Then, the use of these columns are helpful to clean DNA after such step. Here we present the detailed protocol.

\section{Solutions}

1. STE (Sucrose-Tris-EDTA): $0.25 \mathrm{M}$ sucrose, 0.03 M Tris, 0.05 M EDTA.

2. $2 \times \mathrm{CTAB}$ (cetyltrimethyl ammonium bromide) extraction buffer: $100 \mathrm{mM}$ Tris- $\mathrm{HCl}(\mathrm{pH}=8.0), 1.4 \mathrm{M} \mathrm{NaCl}, 20 \mathrm{mM}$ EDTA (pH $=8.0), 2 \%(\mathrm{w} / \mathrm{v})$ PVPP (polyvinyl polypyrrolidone), $0.1 \%(\mathrm{v} / \mathrm{v})$ $\beta$-mercaptoethanol (include to the solution immediately prior to use).

3. Chloroform: Isoamyl alcohol (24:1).

4. $7.5 \mathrm{M}$ ammonium acetate $\mathrm{pH} 7.5$

5. Isopropanol.

6. $80 \%$ ethanol.

7. TE buffer solution: $10 \mathrm{mM}$ Tris- $\mathrm{HCl}(\mathrm{pH}=8), 1 \mathrm{mM}$ EDTA. 
8. Buffer AW - aka Ethanol Wash from Qiagen kit (or just 70\% Ethanol).

9. Buffer AE - aka Elution Buffer from Qiagen kit (or use the regular TE).

10. DNeasy Mini spin columns (or other silica-based columns like blood/tissue kit columns).

11. Liquid nitrogen.

12. Carbon steel balls.

\section{DNA extraction procedure}

1. Place $20-25 \mathrm{mg}$ of dried leaf tissue in a $1.5 \mu \mathrm{L}$ micro-centrifuge tube with three $1 / 8$-inches' carbon steel balls and stir it on vortex until obtain a fine powder, or snap freeze by suspending the tube in liquid nitrogen and grind to a fine powder (see DNA pre-extraction procedure).

2. Add $1 \mathrm{~mL}$ of freshly made STE to the ground plant tissue Vortex, then centrifuge at $6000 \mathrm{rpm}$ for $10 \mathrm{~min}$. Discard supernatant with a wide-bore pipet tip and repeat STE wash.

3. Discard supernatant with a wide-bore pipet tip and then centrifuge newly at $20000 \mathrm{rpm} \times 3 \mathrm{~min}$ and discard the rest of supernatant.

4. Add $750 \mu \mathrm{L}$ CTAB buffer and 3.0 $\mu \mathrm{L} \beta$-mercaptoethanol.

5. Vortex for 1 minute.

6. Incubate for $1-2$ hours at $60^{\circ} \mathrm{C}$ (vortex during 1 min every 30 $\min$ ).

7. At the end of 2 hours, give final vortex for 20 seconds.

8. Centrifuge at $5000 \mathrm{rpm}$ for $3 \mathrm{~min}$ at room temperature.

9. Transfer the supernatant into another microcentrifuge tube and add $700 \mu \mathrm{L}$ chloroform: isoamyl alcohol (24:1). Stir vigorously by hand.

10. Centrifuge at $10,000 \mathrm{rpm}$ for $10 \mathrm{~min}$.

11. Transfer the supernatant into another microcentrifuge tube and add $700 \mu \mathrm{L}$ chloroform: isoamyl alcohol (24:1). Stir vigorously by hand.

12. Centrifuge at $10,000 \mathrm{rpm}$ for $10 \mathrm{~min}$.

13. Determine the amount of supernatant and add ammonium acetate $(40 \mu \mathrm{L}$ ammonium acetate to every $500 \mu \mathrm{L}$ of supernatant $)$ and cold isopropanol $(291 \mu \mathrm{L}$ isopropanol to every $500 \mu \mathrm{L}$ of supernatant)

14. If after inverting gently a pellet can be seen, continue with step15. If not, leave the samples cooling at $-20^{\circ} \mathrm{C}$ overnight, and continue with step 17 .

15. Leave at room temperature for $1-5 \mathrm{~min}$ and transfer DNA pellet using a wide-bore pipet tip into a micro-centrifuge tube containing $800 \mu \mathrm{L}$ of $80 \%$ ethanol. Wash pellet by gently inverting several times. Transfer DNA pellet (using a wide-bore pipet tip) to a new micro-centrifuge tube and repeat ethanol wash.

16. Dry the pellet and suspend in $60-100 \mu \mathrm{L}$ of TE (now you have DNA ready to use).
17. Transfer $650 \mu \mathrm{L}$ of the mixture into a DNeasy Mini spin column (or blood/tissue kit column) placed in a $2 \mathrm{ml}$ collection tube. Centrifuge for $1 \mathrm{~min}$ at $\geq 8000 \mathrm{rpm}$ ) Discard the supernatant. Repeat this step with the remaining sample.

18. Place the spin column into a new $2 \mathrm{ml}$ collection tube. Add $500 \mu \mathrm{L}$ Buffer AW, and centrifuge for $1 \mathrm{~min}$ at $\geq 8000 \mathrm{rpm}$. Discard the supernatant.

19. Add another $500 \mu \mathrm{L}$ Buffer AW. Centrifuge for $2 \mathrm{~min}$ at 20000 rpm

1. (Note: Remove the spin column from the collection tube carefully so that the column is not exposed to the supernatant.)

20. Transfer the spin column to a new $1.5 \mathrm{ml}$ or $2 \mathrm{ml}$ microcentrifuge tube.

21. Add $50-60 \mu \mathrm{L}$ Buffer $\mathrm{AE}$ for elution. Incubate for $10 \mathrm{~min}$ at room temperature $\left(15-25^{\circ} \mathrm{C}\right)$. Centrifuge for $1 \mathrm{~min}$ at $\geq 8000$ rpm.

\section{Repeat step 21}

Finally, all DNA samples extracted with the protocols were tested for the degree of contamination and the amount of DNA obtained on a Thermo Scientific NanoDrop.

DNA amplification and sequencing -A region of approximately 800 bp corresponding to the gene matK and a region $438 \mathrm{bp}$ corresponding to the gene trnL-F were amplified using the following primers:

Forward matK-xf TAA TTT ACG ATC AAT TCA TTC and reverse matK-MALP ACA AGA AAG TCG AAG TAT, ${ }^{37}$ forward trnL GGT TCA AGT CCC TCT ATC CC and reverse trnF ATT TGA AGT GGT GAC ACG AG. ${ }^{38}$ PCR was performed in a total volume of $25 \mu \mathrm{L}$; containing $2.0 \mu \mathrm{L}$ BSA (Bovine Serum Albumin) $(20 \mathrm{mg} / \mathrm{mL}$ ), $2.5 \mu \mathrm{L} 10 \mathrm{x}$ PCR buffer, $2.5 \mu \mathrm{L} \mathrm{MgCl}_{2}(25 \mathrm{mM}), 2.0 \mu \mathrm{L}$ dNTP mixture $(2.5 \mathrm{mM}), 0.75 \mu \mathrm{L}$ each primer $(10 \mu \mathrm{M}), 0.15 \mu \mathrm{L}$ Taq polymerase (recombinant) Thermo scientific, $2 \mu \mathrm{L}$ template DNA (containing 5-50 ng genomic DNA), and finally distilled deionized water to give a final volume of $25 \mu \mathrm{L}$. The PCR profiles for trnL-trnF and matK, included an initial denaturation step at $94^{\circ} \mathrm{C}$ for $1 \mathrm{~min}$, followed by 30 cycles of $50 \mathrm{~s}$ at $94^{\circ} \mathrm{C}, 1 \mathrm{~min}$ at $52^{\circ} \mathrm{C}, 80 \mathrm{~s}$ at $72^{\circ} \mathrm{C}$ and a final extension at $72^{\circ} \mathrm{C}$ for $12 \mathrm{~min}$. PCR products were checked on $1 \%$ agarose gels. ${ }^{3}$ When bands observed in electrophoresis gel were not clear enough, nested PCRs were used, to increase concentration of DNA sequences in such samples. Subsequently matK and trnL-F PCR products corresponding to the species Boehmeria aspera, B. bullata, B. celtidifolia, B. pavonii, B. ramiflora, Boehmeria ulmifolia, Phenax hirtus, P. mexicanus, Phenax sp and Pouzolzia occidentalis were sent to Macrogen Inc. to be sequenced in one way with the forward primers. The sequences were analysed using the software BioEdit and AliView (Table 2).

\section{Results}

\section{Anatomical analysis}

The presence of mucilaginous canals, and the presence of high amounts of mucilages in both leaves and stems all the specimens analysed were detected (Figures 1\&2). The presence of abundant cystoliths, mainly in the adaxial surface of leaves were also found for all samples (Figure 2). Calcium oxalate crystals forming druses were also detected for the specimens. The analysis also revealed the presence of tannins bordering the vascular bundle of leaves (Figures $1 \& 2)$. 


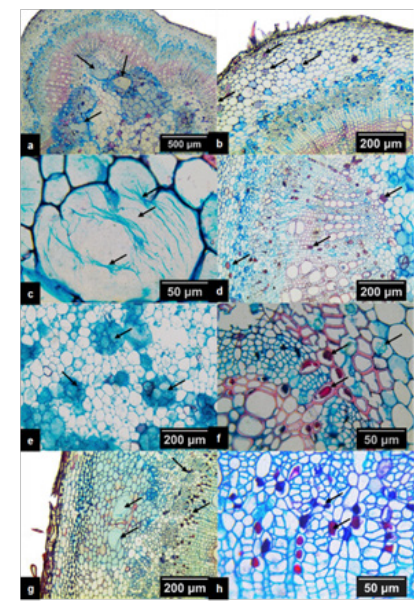

Figure I Optical microscopy of stem transverse section cuts stained with Safranin and Alcian blue in three Urticaceae members. The structures of interest are indicated with black arrows. (a, b, c) Boehmeria aspera; (a) 4x view showing mucilaginous canals in the stem pith. A dark area can be seen around them; it corresponds to the mucilage after been poured because of the cut (b) I0x view from the same cut. Druse crystals (purple) and cells containing mucilage (blue) can be seen. (c) $40 x$ magnification of a mucilaginous canal with strands of mucilage remnants. (e, e, f) Boehmeria caudata; (d) 4x view showing intrusions of cells containing tannins in both xylem and phloem. (e) I0x view showing mucilaginous canals in the stem pith. (f) 40x view showing cells with tannins (red) and druses (blue). (g, h) Coussapoa villosa; (g) I0x view showing mucilaginous canals in the cortex and intrusions of tannins in both xylem and phloem. (h) 10x magnification of those cells containing tannins.

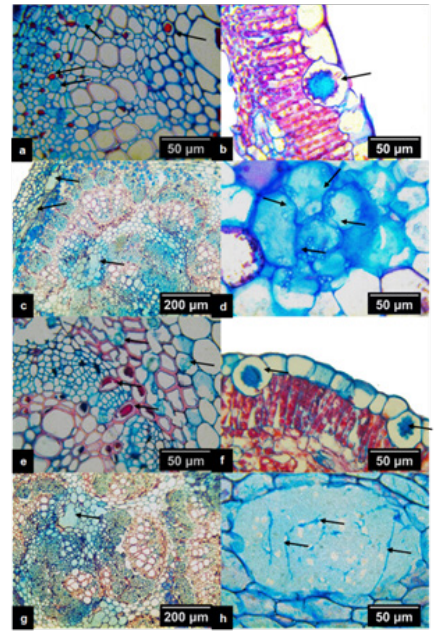

Figure 2 Optical microscopy of leaf transverse section cuts stained with Safranin and Alcian blue, in three Urticaceae members. The structures of interest are indicated with black arrows. (a, b) Boehmeria aspera; (a) 40x view of a leaf mi vein where intrusions of cells containing tannins (red) and druses (blue) can be seen. (b) $40 x$ view of a leaf blade showing an idioblast partially immersed in both the epidermis and the palisade parenchyma, which contains a cystolith. (c, d, e, f) Boehmeria caudata; (c) I0x view of a leaf mi vein where mucilaginous canals can be seen bordering the vascular bundles. (d) 40x magnification of one of those canals. A darkish blue mucilage can be seen around them. (e) 40x view of a portion of the vascular bundle showing intrusions of cells containing tannins in both xylem and phloem and cells containing druses outside. (f) $40 x$ view of a leaf blade showing two idioblasts partially immersed in both the epidermis and the palisade parenchyma, which contain cystoliths. ( $\mathrm{g}, \mathrm{h}$ ) Coussapoa villosa; $(\mathrm{g})$ I0x view of a leaf mi vein where mucilaginous canals can be seen bordering the vascular bundles. (h) $40 x$ magnification of one of those canals.

\section{DNA pre-extraction procedure}

The grinding with carbon steel balls was successful with samples drying rough and breakable to touch, since from all of them a fine powder was obtained. On the contrary, samples containing an arachnoid tomentum or those with very feeble trichomes did not yielded any fine powder. Liquid nitrogen was successful with both type of leaves.

\section{DNA extraction}

The Dneasy Plant Mini Kit protocol did not extract amplifiable DNA from herbarium specimens, neither samples from silica gel dried material yielded good results. It can be attributed to the fact that this protocol does not implement a method to clean mucilages and polysaccharides excess that we found in Urticaceae specimens (Figures 3 (A\&B)). The Dneasy Plant Mini Kit (QIAgen) for plants with leaves containing sclerenchyma strands developed by Drábková 22 was successful for obtaining DNA from silica gel dried material in some specimens like B. aspera, but none of the samples from herbarium generated amplifiable DNA with this protocol (Figures $3(\mathrm{~A} \& \mathrm{~B}))$.

The STE/CTAB Method for Microscale DNA Extraction from Polysaccharide-Rich Plants, ${ }^{22}$ was successful to obtain amplifiable DNA from silica gel samples. However, no DNA was obtained from herbarium specimens under this protocol (Figures 3 (A\&B)). The CTAB protocol modified by Quintanilla et al., ${ }^{35}$ extracted good quality DNA from both herbarium and silica gel samples, but in many cases where plants possessed high amounts of mucilages, it was almost impossible to re-suspend DNA in the elution buffer (Figure 3, Figure $4(C \& D))$. Finally, the protocol we developed combining techniques from the others, worked very well for both silica gel dried material and herbarium samples (Figure 3, Figure $4(\mathrm{~A} \& \mathrm{~B})$ ).

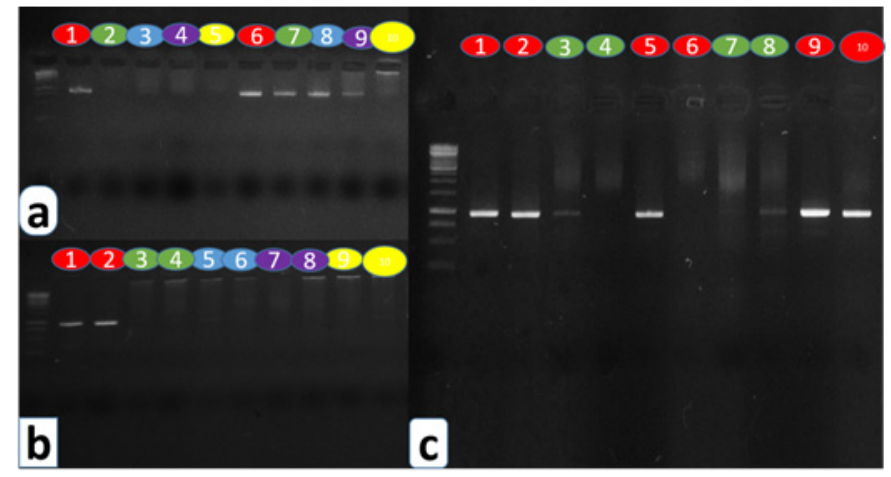

Figure 3 Electrophoresis results for DNA extracted from herbarium and field specimens. All samples were amplified using matK primers. Coloured circles represent the five protocols used, where ours (red), Quintanilla's (green), STE/ CTAB by Drábková et al (Blue), Dneasy Plant Mini Kit modified by Drábková et al (purple) and Standard Dneasy Plant Mini Kit (yellow). (a) results of the five protocols when DNA from herbarium material was amplified for Boehmeria. clidemioides (numbers from I to 5) and DNA from field samples was amplified for B. aspera (numbers from 6 to 10). (b) DNA amplification results from herbarium samples for Boehmeria chiangmaiensis (numbers I, 3, 5, 7, 9) and Boehmeria pilosiuscula (numbers 2, 4,6,8). (c) Comparison among nested PCRs from herbarium material using Quintanilla's and our protocol. Amplifications correspond to Boehmeria tailandica (numbers I and 3), B. tricuspis (numbers 2 and 4), Phenax hirtus (numbers 5 and 7), Pouzolzia formicaria (numbers 6 and 8) and Debregeasia dentata (numbers 9 and 10 ). 


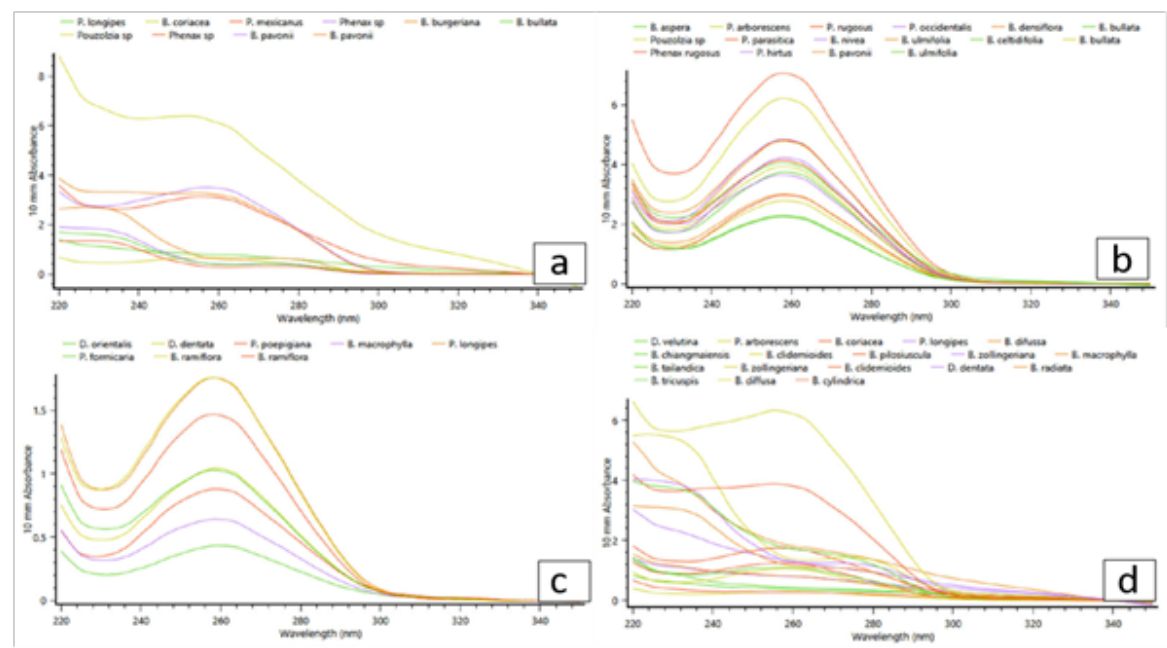

Figure 4 Nano drop results of extracted DNA using our modified protocol (upper) and Quintanilla's (lower). (a and c) DNA extracted from silica-gel dried samples. (b and d) DNA extracted from Herbarium specimens. Well-defined pick at $206 \mathrm{~nm}$ (hood shape) like in (a) and (b) indicate good DNA quality, while poorly defined as in (c) and (d) indicate DNA contamination. The higher the pick at $260 \mathrm{~nm}$, the higher the DNA concentration.

DNA amplification and sequencing -DNA was extracted from herbarium and/or dried silica gel material with all protocols used, as it was deduced in electrophoresis performed on total genomic DNA. However, not all protocols were suitable to obtain amplifiable DNA; since amplification depends on a series of factors, such as the origin of samples (herbarium or dried silica gel material), the amount of time of DNA precipitation during the extraction, the removal of polysaccharides and tannins among others. DNA from herbarium specimens was only amplified with either Quintanilla's or our modified protocol, being this process more successful with ours (Figure 3C). Many samples from this type of DNA also needed nested PCRs. DNA coming from silica gel from B. aspera, B. caudata and B. ulmifolia were amplified with all protocols except for the standard Dneasy Plant Mini Kit protocol. (Figure 3A).

\section{Discussion}

Urticaceae members are characterized by the presence of exudate and cystoliths. With the anatomical analysis, we found that in fact, these plants possess mucilaginous canals with possibly polysaccharides inside them; they also possess many tannins (Figures 1\&2). At the beginning, we thought that cystoliths could interfere with DNA extraction, but in fact, it was the opposite. Plants possessing high amounts of these structures yielded amplifiable DNA with four of the five protocols used. The presence of cystoliths in leaves helped with grinding, since they ruptured the tissues when the pestle rubs against them. There were also no reports in the literature where evidence is provided about the presence of cystoliths affecting DNA extraction.

The presence of tannins interfered with DNA extraction, since they are accumulations of polyphenols. When plants are dried for herbarium preservation at high temperatures $\left(60^{\circ} \mathrm{C}\right.$ or more), polyphenols are oxidized and since the DNA is a reducing agent, they bind each other, avoiding DNA-polymerase to successfully amplify such DNA. ${ }^{26,30}$ This is the reason why protocols which emphasize on eliminating polyphenols, like those using $\beta$-mercaptoethanol, were more successful (see below the session "DNA extraction").

Mucilages are complex mixtures of proteins, polysaccharides and other substances. Urticaceae is considered a plant family producing exudate, and as shown in Figures $1 \& 2$, that exudate is produced by mucilaginous canals. Mucilages have been reported to interfere with DNA extraction. ${ }^{32}$ In our case mucilages did interfered, even with samples coming from herbarium material. DNA from samples with high amounts of mucilage formed a compacted pellet, which then did not re-suspend in the elution buffer (see below the session "DNA extraction").

We tested carbon steel balls to grind tissues because we wanted to find an efficient way, without using liquid nitrogen, since in many laboratories, it is difficult to access this material and the usual procedure with it, also ends up wasting part of the sample. In spite that the first is appropriate to grind many of the tissues, it failed, when the leaves do not have a rough drying and are brittle to contact. Even though liquid nitrogen was suitable in any case, we recommend the use of carbon steel balls, when dealing with small amounts of samples like those sometimes provided by herbaria. With carbon steel balls, the sample is grinded inside the microcentrifuge tube, avoiding losing part of it, as it happens when it is performed in a mortar with liquid nitrogen. When nitrogen was necessary we tried to immerse directly the microcentrifuge tube with the sample in liquid nitrogen, in order to avoid the use of mortar, but it took a considerable amount of time to freeze the sample by this method.

The Dneasy Plant Mini Kit protocol seems not to be useful to extract DNA from silica gel dried material nor when material come from herbaria. As discussed in literature. ${ }^{19-24}$ samples from herbaria, very often have degraded DNA, since many of them are old or the DNA is damaged due to the preservation methods used; sample drying, fumigation among others. ${ }^{26-28}$ For instance, to achieve successful results with such samples it is necessary to improve certain steps in protocols (see below), but this protocol does not emphasize on improving the extraction of this type of DNA. We believe that this protocol failed to extract amplifiable DNA from samples dried in silica gel, likely due to the high amounts of mucilage and polysaccharides in such samples, since this protocol does not highlight on eliminating such substances either.

The fail of Dneasy Plant Mini Kit (QIAgen) for Plants with Leaves Containing Sclerenchyma Strands protocol developed by Drábková 
et al., ${ }^{22}$ is probably because it consists in merely modifications of time of samples exposure to the QIAgen's buffers, and patterns of centrifugation. However, it does not improve a step to eliminate tannins and polysaccharides, which are kept after drying of specimens for herbarium preservation.

The STE/CTAB Method for Microscale DNA Extraction from Polysaccharide-Rich Plants ${ }^{22}$ was successful to extract DNA from silica gel preserved material, probably because as it includes $\beta$-mercaptoethanol in the CTAB solution it helps to keep polyphenols to co-precipitate with DNA. Nevertheless, the main achievement of this protocol is the STE solution employed at the beginning, to remove the excess of polysaccharides. However, the step 6 in this protocol implies the transfer of DNA pellet using a wide-bore pipette tip into a microcentrifuge tube containing $800 \mu \mathrm{L}$ of $80 \%$ ethanol and it represent a disadvantage, since when extracting DNA from herbarium samples it is difficult to obtain such a pellet, due to degradation and less amounts of DNA in tissues.

The CTAB protocol modified by Quintanilla et al., ${ }^{35}$ was successful in some cases because it also uses $\beta$-mercaptoethanol to prevent coprecipitation of polyphenols with DNA, but it does not incorporate any step to clean DNA from polysaccharides. Another issue with this protocol is the fact that it does not include columns for filtering DNA after precipitation, and we believe that after long periods of DNA precipitation other substances can also co-precipitate with DNA. The use of filtering columns could improve the cleaning of DNA from these substances. At the same time, the use of columns would prevent remnants of polysaccharides to co-precipitate.

The protocol we standardized was very successful because it begins with STE solution, in order to eliminate polysaccharides, which are very common in Urticaceae members (Figures 1\&2). The protocol then proceeds with CTAB solution, in which we decided to include 2.5 to $3.0 \mu \mathrm{L} \beta$-mercaptoethanol to clean from polyphenols. In samples possessing high amounts of those substances we recommend to use $3.0 \mu \mathrm{L}$ or more of $\beta$-mercaptoethanol. The step 14 is very crucial in this protocol as it gives the option of following two different approaches depending on whether the pellet is or is not formed (when isoamyl alcohol is added to the microcentrifuge tube). In our experience, DNA from dried silica gel samples often forms a pellet, but DNA from herbarium samples often does not. The second approach can always be followed, no matter whether a pellet is or is not formed, but we recommend to follow the first (when pellets are formed), because it is fast, economic and clean. Very often, protocols working with CTAB do not include filtering columns, and then the incorporation of these in our protocol makes it very clean and successful in the second approach of step 14. Finally, the use of carbon steel balls to grind is also very important, since it allows us to waste less amount sample, for instance we reduced the amount of sample used, from $100 \mathrm{mg}$ (proposed by many protocols) to just $20 \mathrm{mg}$.

The ease with which DNA was obtained by using the four protocols tells that DNA extraction is a routine procedure, even when dealing with difficult samples like those from herbarium and those containing polysaccharides and tannins. However, as it was demonstrated in this study, high quality DNA must be obtained in order to successfully amplify a particular region. Since we observed from the electrophoresis and nanodrop analyses that our modified protocol produced the less contaminated samples, we only had those sequenced (Table 2). We can see from Figure 5, that the spectrogram corresponding to the matK sequence from $P$. occidentalis presents high and well-defined peaks, demonstrating that the extraction, amplification and sequencing were successful.

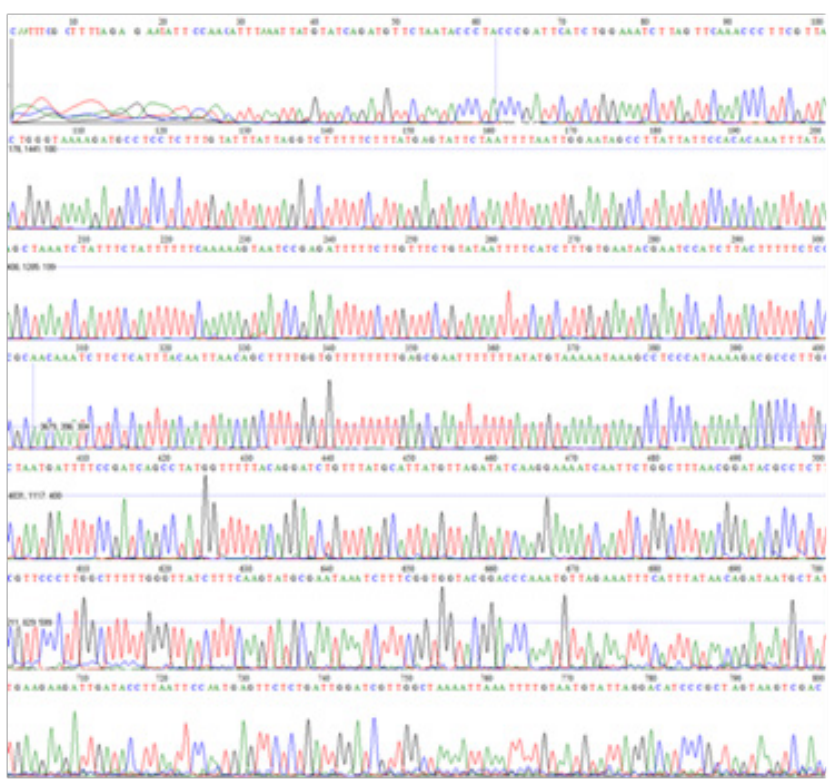

Figure 5 Chromatogram corresponding to matK sequence obtained for Pouzolzia occidentalis. The peaks appear to be high enough and are not mixed between them, which is a good sign of DNA quality.

We can conclude that the protocol we standardized to extract DNA from mucilaginous tissues and herbarium material in Urticaceae was successful. The protocol appears to be low cost, clean and offers the possibility to choose between to different approaches depending on the quality of DNA the investigator is working with. We also propose that this protocol could be used to extract DNA from other plants rather than just Urticaceae. Since this family is very problematic regarding mucilages and polysaccharides, the protocol should be successful with other less challenging plants.

\section{Acknowledgments}

We thank to CPBiol (Consejo Profesional de Biologia) for their partial financing on this project, Antioquia's University; specially Laboratorio de Estudios Botánicos and Herbarium HUA for bringing us the facilities and support to carry out this study.

\section{Conflicts of interest}

The authors declare no conflicts of interest.

\section{References}

1. Stevens PF. Angiosperm Phylogeny Website. Version 14; 2017.

2. Takhtajan A. Flowering plants. 2009.

3. Wu ZY, Monro AK, Milne RI, et al. Molecular phylogeny of the nettle family (Urticaceae) inferred from multiple loci of three genomes and extensive generic sampling. Mol Phylogenet Evol. 2013;69(3):814-827.

4. Wilmot Dear CM. The new world species of Boehmeria and Poulzozia. Opera Bot 129. 1996.

5. Wilmot Dear CM, Friis I. The old World species of Boehmeria (Urticaceae, tribus Boehmerieae). A taxonomic revision. Blumea Biodiversity, Evolution and Biogeography of Plants. 2013;58(2):85216.

6. Machado CA, Jousselin E, Kjellberg F, et al. Phylogenetic relationships, historical biogeography and character evolution of fig-pollinating wasps. Proc Biol Sci. 2001;268(1468):685-694. 
7. Sytsma KJ, Morawetz J, Chris Pires J, et al. Urticalean rosids: Circumscription, rosid ancestry, and phylogenetics based on $\mathrm{rbcL}$, trnL-F, and ndhF sequences. Am J Bot. 2002;89(9):1531-1546.

8. Hadiah JT, Conn BJ, Quinn CJ. Infra-familial phylogeny of Urticaceae, using chloroplast sequence data. Aust Syst Bot. 2008;21(5):375-385.

9. Hadiah JT, Quinn CJ, Conn BJ. Phylogeny of Elatostema (Urticaceae) using chloroplast DNA data. Telopea. 2003;10:235-246.

10. Datwyler SL, Weiblen GD. On the origin of the fig: Phylogenetic relationships of Moraceae from NDHF sequences. Am J Bot. 2004;91(5):767-777.

11. Liao L, Li TJ, Liu ZL, et al. Phylogenetic Relationship of Ramie and Its Wild Relatives Based on Cytogenetic and DNA Sequence Analyses. Acta Agron Sin. 2009;35(10):1778-1790.

12. Zhang SD, Soltis DE, Yang Y, et al. Multi-gene analysis provides a wellsupported phylogeny of Rosales. Mol Phylogenet Evol. 60(1):21-28.

13. Misiewicz TM, Zerega NC. Phylogeny, biogeography and character evolution of Dorstenia (Moraceae). Edinburgh J Bot. 2012;69(3):413440 .

14. Wu ZY, Milne RI, Chen CJ, et al. Ancestral state reconstruction reveals rampant homoplasy of diagnostic morphological characters in urticaceae, conflicting with current classification schemes. PLoS One. 2015;10(11):0141821.

15. Kim C, Deng T, Chase M, et al. Generic phylogeny and character evolution in Urticeae (Urticaceae) inferred from nuclear and plastid DNA regions. Taxon. 2015;64(1):65-78

16. Treiber EL, Gaglioti AL, Romaniuc Neto S, et al. Phylogeny of the Cecropieae (Urticaceae) and the Evolution of an Ant-Plant Mutualism. Syst Bot. 2016;41(1):56-66.

17. Borges A, Rosa M, Recchia G, et al. CTAB methods for DNA extraction of sweet potato for microsatellite analysis. Sci Agric. 2009;66(4):529534.

18. Wallinger C, Juen A, Staudacher K, et al. Rapid plant identification using species- and group-specific primers targeting chloroplast DNA. PLoS One. 2012;7(1):29473.

19. Rogers SO, Bendich AJ. Extraction of DNA from milligram amounts of fresh, herbarium and mummified plant tissues. Plant Mol Biol. 1985;5(2):69-76.

20. Cubero OF, Crespo A, Fatehi J, et al. DNA extraction and PCR amplification method suitable for fresh, herbarium-stored, lichenized, and other fungi. Plant Syst Evol. 1999;216(3-4):243-249.

21. Khanuja SPS, Shasany AK, Kumar S. Rapid isolation of DNA from and fresh samples of plants producing large amounts of secondary metabolites and essential oils. Plant Mol Biol Report. 1999;17(1):74.

22. Drábková L, Kirschner J, Vlĉek Ĉ. Comparison of seven DNA extraction and amplification protocols in historical herbarium specimens of Juncaceae. Plant Mol Biol Report. 2002;20(2):161-175.
23. Remarchuk K, Kumary Ubayasena, J Hugo Cota Sánchez. Readyto-Use DNA extracted with a CTAB method adapted for herbarium specimens and mucilaginous plant tissue. Plant Mol Biol Report. 2006;24:161-167

24. Särkinen T, Staats M, Richardson JE, et al. How to open the treasure chest? optimising DNA extraction from herbarium specimens. PLoS One. 2012;7(8):43808.

25. Clayton M Costa, R Roberts $\mathrm{P}$. Techniques for improving the quality and quantity of DNA. Phytoneuron. 2014;48:1-8.

26. Porebski S, Bailey LG, Baum BR. Modification of a CTAB DNA extraction protocol for plants containing high polysaccharide and polyphenol components. Plant Mol Biol Report. 1997;15(1):8-15.

27. Staats M, Cuenca A, Richardson JE, et al. DNA damage in plant herbarium tissue. PLoS One. 2011;6(12):28448.

28. Sahu SK, Thangaraj M, Kathiresan K. DNA extraction protocol for plants with high levels of secondary metabolites and polysaccharides without using liquid nitrogen and phenol. ISRN Mol Biol. 2012:1-6.

29. Wilkins TA, Smart LB. Isolation of RNA from plant tissue. A Laboratory Guide to RNA. 1996;21-42.

30. Katterman FR, Shattuck VI. An effective method of DNA isolation from the mature leaves of Gossypium species that contain large amounts of phenolic terpenoids and tannins. Prep Biochem. 1983;13(4):347-359.

31. Doyle JJ, Doyle JL. Isolation of plant DNA from fresh tissue. Focus (Madison). 1990;12:13-15

32. Shepherd LD, McLay TGB. Two micro-scale protocols for the isolation of DNA from polysaccharide-rich plant tissue. $J$ Plant Res. 2011;124(2):311-314

33. Harris S. DNA analysis of tropical plant species: an assessment of different drying methods. Plant Syst Evol. 1993;188(1-2):57-64.

34. Wilfinger WW, Mackey K, Chomcynski P. Effect of $\mathrm{pH}$ and Ionic Strength on The Spectrophotometric Asssessment of Nucleic Acid Purity. Biotechniques. 1997;22(3):474-481.

35. Quintanilla S, Ortiz P, Bernal JE, et al. Molecular characterization and phylogenetic relationships among genera of the subtribe Oncidiinae (Epidendroideae: Orchidaceae) and a new genus tentatively called "Santanderella." Phytologia. 2011;93(3):388-406.

36. Dunning L, Savolainen V. Broad-scale amplification of matK for DNA barcoding plants, a technical note. Bot J Linn Soc. 2010;164(1):1-9.

37. Ford C, Ayres K, Haider N, et al. Selection of candidate DNA barcoding regions for use on land plants. Bot J Linn Soc. 2009;159(1):1-11.

38. Taberlet P, Gielly L, Pautou G, et al. Universal primers for amplification of three non-coding regions of chloroplast DNA. Plant Mol Biol. 1991;17(5):1105-1109. 